\title{
Pemanfaatan Elisitor Ekstrak Tumbuhan dalam Budidaya Tanaman Ubi Jalar (Ipomoea batatas L.)
}

\author{
Henny L. Rampe ${ }^{1 *}$, Stella D. Umboh ${ }^{1}$, Marhaenus J. Rumondor ${ }^{1}$ dan Meytij J. Rampe ${ }^{2}$ \\ ${ }^{1}$ Jurusan Biologi, Fakultas Matematika dan Ilmu Pengetahuan Alam \\ Universitas Sam Ratulangi Manado \\ ${ }^{2}$ Jurusan Kimia, Fakultas Matematika dan Ilmu Pengetahuan Alam \\ Universitas Negeri Manado \\ *Penulis Korespondensi, Henny L. Rampe, Jurusan Biologi FMIPA Universitas Sam Ratulangi Manado 95115 \\ Email : hennyrampe@unsrat.ac.id
}

\begin{abstract}
ABSTRAK
Tanaman elisitor adalah suatu tanaman yang mengandung senyawa kimia yang dapat memicu respon fisiologi, morfologi dan akumulasi fitoaleksin, meningkatkan aktivasi dan ekspresi gen yang terkait dengan biosintesis metabolit sekunder. Elisitor dapat menginduksi resistensi tumbuhan. Tujuan dan target khusus yang dicapai dalam kegiatan ini adalah peningkatan pengetahuan dan ketrampilan penggunaan elisitor ekstrak tumbuhan dalam budidaya ubi jalar, yang memberikan dampak positif yaitu mengurangi ketergantungan terhadap penggunaan pestisida kimia / sintetik. Kegiatan dilaksanakan pada kelompok tani Wawo Sumpaken dan Diakonia di Kelurahan Matani Dua, Kecamatan Tomohon Tengah Kota Tomohon. Elisitor ekstrak tumbuhan yang digunakan adalah daun bayam duri (Amaranthus spinosus), alang-alang (Imperata cylindrica), daun alpukat (Persea americana), daun mangkokan (Nothopanax scutellarium), daun sirsak (Annona muricata), daun sirih (Piper betle) dan daun salam (Syzygium polyanyhum). Tahapan kegiatan yang dilakukan adalah : 1) Pre-test, 2) Penyampaian materi, 3) Latihan pembuatan elisitor ekstrak tumbuhan, 4) Post-test, dan 5) Evaluasi dan monitoring. Hasil kegiatan penyuluhan menunjukkan terjadi peningkatan pengetahuan berdasarkan hasil post-test, yaitu sebanyak 3 orang $(10 \%)$ memperoleh nilai $8,76-100,11$ orang $(36.67 \%)$ memperoleh nilai $7.51-8.75$, dan 12 orang (40\%) memperoleh nilai dengan range 6.26 - 7.50. Kegiatan Program Kemitraan Masyarakat (PKM) dapat memotivasi petani menggunakan pestisida nabati dan elisitor ekstrak tumbuhan dalam kegiatan budidaya tanaman pangan.
\end{abstract}

Kata kunci : Elisitor ekstrak tumbuhan, Ubi Jalar (Ipomoea batatas)

\section{PENDAHULUAN}

\section{Analisis Situasi}

Kota Tomohon berada di wilayah pegunungan yang terletak antara $01^{\circ} 18 ' 51^{\prime \prime}$ Lintang Utara dan $124^{\circ} 49^{\prime} 40^{\prime \prime}$ Bujur Timur, memiliki luas $147,21 \mathrm{~km} 2$ dan berada pada ketinggian 400-1500 meter dpl dengan kisaran suhu $18^{\circ} \mathrm{C}-30^{\circ} \mathrm{C}$. Dengan kecepatan angin rata-rata $3,35 \mathrm{knot} / \mathrm{bulan}$, kelembapaan udara rata-rata 90,67\%/bulan, temperatur udara $22,33{ }^{\circ} \mathrm{C} / \mathrm{bulan}$, curah hujan rata-rata $291,04 \mathrm{~mm} / \mathrm{bulan}$ dan tekanan udara 940,10 (BPS, 2017).

Peningkatan jumlah penduduk Kota Tomohon terjadi pada tahun 2007, walaupun Bioteknologi di tahun 2007-2010 masih bersifat angka proyeksi tetapi penduduk Kota Tomohon terus mengalami peningkatan. Pada tahun 2011 peningkatan jumlah penduduk Kota Tomohon meningkat sangat signifikan sekitar 8,56\% atau sebesar 91.553 jiwa diikuti dengan pertambahan luas area Kota Tomohon dari $114,20 \mathrm{Km} 2$ menjadi 147,21 km2. Jumlah penduduk Kota Tomohon terus meningkat sampai pada tahun 2014 penduduk Kota Tomohon berjumlah 95.157 jiwa (Arotaa, et al., 2016)

Kota Tomohon mengalami perkembangan pesat akibat kegiatan perekonomian, bisnis dan pertanian. Sektor 
VIVABIO

Jurnal Pengabdian Multidisiplin

pertanian telah berperan dalam perekonomian nasional melalui perolehan devisa, penyediaan pangan, dan bahan industri, pengetasan kemiskinan, menciptakan lapangan kerja, dan meningkatkan pendapatan masyarakat (Laoh, 2008).

Usaha pertanian selalu menghendaki adanya peningkatan produksi pertanian dari segi kualitas dan kuantitasnya. Untuk mencapai hal tersebut, salah satu pendukung pertanian yaitu penggunaan pestisida, yang bertujuan mengendalikan dan mencegah gangguan serangga, hewan pengerat, nematoda, gulma, virus, bakteri dan berbagai organisme pengganggu tanaman.

Saat ini para petani lebih banyak menggunakan pestisida sintetik / kimia, dibanding dengan pestisida nabati, karena pestisida sintetik pembuatannya masal dan murah, serta mempunyai daya bunuh yang cepat (Sastrodihardjo, 1984). Penggunaan pestisida harus yang benar, artinya pestisida yang diaplikasikan harus mampu menampilkan efesiensi biologisnya yang optimal (efektif dan ampuh), dan bijaksana artinya menekan dampak negatif pestisida terhadap pengguna, konsumen dan lingkungan serta bersifat ekonomis dan efisien.

Penggunaan pestisida yang berlebihan dan cara aplikasi yang tidak bijaksana memberikan dampak negatif yaitu pencemaran lingkungan, kematian hewan non-target, penyederhanaan rantai makanan alami dan keragaman hayati, bioakumulasi / biomagnifikasi, resistensi hama dan terbunuhnya musuh alami (Kardinan, 2001., Havelka, 2009, Mallarangeng, et al., 2012)

Dinas pertanian, Peternakan dan Perikanan (DISTANAKAN) Kota Tomohon, mengacuh dari visi dan misi, melalui program pengembangan pertanian, mengsyaratkan jaminan produk pertanian

harus mempunyai atribut : aman dikonsumsi (food safety attributes), punya kandungan nutrisi tinggi (nutritional attributes) dan ramah lingkungan (Eco Labelling Attributes). Maka untuk merealisasi jaminan produk pangan, beberapa program yang dilakukan antara lain : 1) Program peningkatan ketahanan pangan, 2) Program pengembangan agribisnis, dan 3) Program pengembangan pertanian organik dan penggunaan pestisida.

Konsep pertanian ramah lingkungan adalah konsep pertanian yang mengedepankan keamanan seluruh komponen yang ada pada lingkungan ekosistem dimana pertanian ramah lingkungan mengutamakan untuk meninggalkan dampak negatif bagi lingkungan. Pestisida nabati adalah pestisida yang bahan aktifnya berasal dari tanaman atau tumbuhan dan bahan organik lainya yang berkhasiat mengendalikan serangan hama dan patogen pada tanaman. Pestisida nabati saat diaplikasikan akan membunuh hama dan patogen saat itu juga dan setelah hamanya mati maka residunya akan hilang di alam. Dengan demikian produk terbebas dari residu pestisda sehingga aman dikonsumsi manusia. Pestisida nabati dapat menjadi alternatif pengendalian hama yang aman dibanding pestisida sintetik.

Kelebihan pestisida nabati yaitu 1) Teknologi pembuatannya lebih mudah dan murah, sehingga memungkinkan untuk dibuat sendiri dalam skala rumah tangga. 2) Pestisida nabati tidak menimbulkan efek negatif bagi lingkungan maupun terhadap makhluk hidup, sehingga, relatif aman untuk digunakan. 3)Tidak beresiko menimbulkan keracunan pada tanaman, sehingga, tanaman yang diaplikasikan pestisida nabati jauh lebih sehat dan aman dari pencemaran zat 


\section{VIVABIO}

Jurnal Pengabdian Multidisiplin

kimia berbahaya. 4) Tidak menimbulkan resistensi (kekebalan) pada hama. Dalam artian pestisida nabati aman bagi keseimbangan ekosistem. 5) Hasil pertanian yang dihasilkan lebih sehat serta terbebas dari residu pestisida kimiawi (Suriana, 2012; Butarbutar, 2013).

Untuk mencapai pengembangan pertanian organik dan penggunaan pestisida nabati, beberapa kegiatan yang sudah ada dan sedang digalakkan oleh Dinas terkait Kota Tomohon adalah 1) Pendidikan Lapang Pengendalian Hama Terpadu (PL-PHT) dan pertanian dengan pupuk organik, dan 2) Penyuluhan / pelatihan tentang pestisida nabati.

Hasil survey lapang, di Kota Tomohon sangat berpotensi dikembangkan pertanian berbasis organik dan penggunaan pestisida nabati. Keanekaragman tumbuhan yang dapat digunakan sebagai bahan baku pembuatan pestisida nabati, tersedia dengan populasi spesies yang besar. Berbagai tumbuhan telah diteliti berpotensi elisitor yaitu bayam duri (Amaranthus spinosus), iler/Jawer kotok (Coleus scutellarioides), kenikir (Tagetes erecta), nimba (Azadirachta indica), sirsak (Annona mucicata) dan tapak dara (Cataranthus roseus), menghasilkan senyawa alkaloid, flavonoid, fenolik, steroid dan terpenoid (Gunaeni, et al., 2015), senyawa metabolit sekunder berpotensi dijadikan sumber gen resisten terhadap hama dan patogen (Leiss, et al., 2011).

Tanaman elisitor adalah suatu tanaman yang mengandung senyawa biologis yang dapat menyebabkan peningkatan produksi fitoaleksin bila diaplikasikan pada tumbuhan atau kultur sel tumbuhan. Elisitor dapat berasal dari bakteri, jamur, virus, senyawa polimer karbohidrat, protein, lemak dan mikotoksin sebagai elisitor biotik (Walters et al., 2013), dan elisitor abiotik seperti sinar UV, ion-ion logam dan hormon dan molekul-molekul pengkode resistensi tanaman (Larroque et al., 2013). Elisitor dapat memicu respon fisologis, morfologis dan akumulasi fitoaleksin (Namdeo, 2007), sebagai molekul yang mengaktifkan sinyal transduksi dan menyebabkan aktivasi dan ekspresi gen yang terkait dengan biosisntesis metabolit sekunder (Zhao et al., 2005 dan Angelova, et al., 2006). Verma et al., (1996) mendapatkan aktivator alami misalnya glikosida benzoxazinoid dari Zea mays dan glikosiada isoflavonoid dari kacang-kacangan.

Penelitian elisitor alami telah dilakukan Suganda (2000) yaitu ekstrak beluntas (Plucea indica) berpotensi sebagai penginduksi resistensi tanaman cabai merah terhadap penyakit antraknos Colletotrichum gloesporioides. Selanjutnya Somowiyarjo (2001) menunjukkan penggunaan ekstrak tanaman elisitor daun bunga pukul empat (Mirabilis jalapa), daun bunga pagoda (Clerodendrum japonicum) dapat menginduksi resistensi tanaman cabai terhadap virus Gemini. Tumbuhan sambiloto (Andrographis paniculata) berpotensi elisitor tanaman jahe terhadap penyakit layu bakteri Ralstonia solanacearum.

Kelurahan Matani Dua Kecamatan Tomohon Tengah Kota Tomohon terdapat kelompok tani tanaman pangan dan hortikultura, tanaman hias dan ternak. Jenis tanaman pangan dan hortikultura yang biasanya dibudidaya oleh kelompok tani adalah tanaman sayuran seperti kubis, wortel, sawi, bayam, pok cai dan tanaman jenis kacang-kacangan seperti kacang tanah, buncis, kacang panjang serta tanaman umbiumbian seperti ubi jalar, singkong dan ubi talas. 
VIVABIO

Jurnal Pengabdian Multidisiplin

Hasil konsultasi dengan beberapa kelompok tani di Kelurahan Matani Dua Kota Tomohon, diperoleh informasi bahwa pemanfaatan elisitor ekstrak tumbuhan dalam budidaya tanaman pangan termasuk budidaya ubi jalar masih sangat rendah. Kurangnya pengetahuan disebabkan belum pernah dilaksanakan kegiatan tentang pemanfaatan elisitor ekstrak tumbuhan pada tanaman pangan. Maka dengan dilakukannya kegiatan ini diharapkan memberi pengetahuan, ketrampilan para petani tentang pemanfaatan elisitor ekstrak tumbuhan, bahkan terjadi perubahan perilaku dari penggunaan pestisida sintetik ke pemanfaatan elisitor ekstrak tumbuhan untuk meningkatkan produksi dalam menunjang diversifikasi dan kemadirian pangan.

\section{Tujuan dan Manfaat Kegiatan}

Untuk meningkatkan pengetahuan para petani di Kelurahan Matani Dua Kota Tomohon tentang pemanfaatan elisitor ekstrak tumbuhan dalam budidaya tanaman pangan khususnya ubi jalar, yang sekaligus merealisasi program pengembangan pertanian organik, maka luaran yang ditargetkan adalah :

a) Para petani dalam kelompok tani Wawo Sumpaken dan Diakonia di kelurahan Matani Dua, Kecamatan Tomohon Tengah Kota Tomohon, memperoleh informasi ilmiah tentang manfaat elisitor ekstrak tumbuhan dalam budidaya ubi jalar, dan teknik aplikasi dalam upaya pengendalian hama dan patogen pada tanaman

b) Memperoleh ketrampilan dalam membuat elisitor ekstrak tumbuhan dan teknik aplikasi di lapang

c) Dapat menggunakan elisitor ekstrak tumbuhan dalam budidaya tanaman ubi jalar untuk mengendalikan organisme Pengganggu Tanaman (OPT)

\section{METODE PELAKSANAAN}

\section{Sasaran kegiatan}

Yang menjadi sasaran pelaksanaan kegiatan ini adalah kelompok tani Wawo Sumpaken dan Diakonia

\section{Lokasi kegiatan}

Kegiatan penyuluhan dan pelatihan dilaksanakan di Kelurahan Matani Dua Kota Tomohon

\section{Metode yang digunakan :}

Strategi yang ditawarkan untuk mengurangi penggunaan pestisida sintetik yang tidak bijaksana dan kurangnya pengetahuan manfaat elisitor ekstrak tumbuhan, maka dilakukan penyuluhan dan pelatihan penggunaan elisitor ekstrak tumbuhan dalam budidaya tanaman pangan khususnya ubi jalar. Tahapan kegiatan yang dilakukan : 1) Pre-test, 2) Penyampaian materi, 3) Latihan pembuatan elisitor ekstrak tumbuhan, 4) Post-test dan 5) Evaluasi dan monitoring.

\section{Kegiatan Pre-test}

Pelaksanaan pre-test bertujuan untuk mengetahui pengetahuan awal peserta penyuluhan mengenai pestisida kimia, pestisida nabati dan elisitor ekstrak tumbuhan.

2. Penyampaian Materi, meliputi :

a. Tinjauan umum/pengertian pestisida sintetik dan elisitor ekstrak tumbuhan

b. Dampak negatif pestisida sintetik/kimia bagi konsumen dan lingkungan

c. Pengenalan tumbuh-tumbuhan yang berpotensi elisitor yang dapat menginduksi resistensi

\section{Praktek Pembuatan Elisitor Ekstrak} Tumbuhan

Tujuh jenis tumbuhan elisitor yang diambil di sekitar lahan pertanian yaitu daun bayam duri (Amaranthus spinosus), alang-alang (Imperata cylindrica), daun alpukat (Persea americana), daun mangkokan (Nothopanax 
VIVABIO

Jurnal Pengabdian Multidisiplin

scutellarium), daun sirsak (Annona muricata), daun sirih (Piper betle) dan daun salam (Syzygium polyanyhum). Dasar pemilihan 7 tanaman elisitor yaitu studi pendahuluan dan terdapatnya kandungan metabolit sekunder antara lain fenolik, flavonoid, tanin dan terpenoid.

Setiap tumbuhan dicuci bersih, dikeringanginkan, kemudian dipotong ukuran 1$2 \mathrm{~cm}$ untuk memudahkan dalam pembuatan ekstrak. Selanjutnya dihaluskan dengan blender dan diencerkan 1:1 (w/v) dengan air. Ekstrak tanaman selanjutkan disaring dengan kain kasa, supernatan dimasukkan dalam botol bertutup. Aplikasi elisitor ekstrak tumbuhan pada tanaman ubi jalar dengan melakukan penyemprotan pada seluruh tumbuhan, yang dilakukan pada sore hari.

\section{Kegiatan Post-test}

Kegiatan ini bertujuan untuk mengukur kecercapaian program yang dilakukan, dalam hal ini pengetahuan peserta penyuluhan tentang materi yang disampaikan.

\section{Evaluasi dan Monitoring}

Pada tahap ini dievaluasi sekaligus monitoring capaian dan keberlanjutan ketrampilan yang ditawarkan, mengenai hambatan dan kemungkinan solusi yang dapat dikembangkan untuk mencapai sasaran yang ditargetkan.

\section{HASIL DAN LUARAN YANG DICAPAI}

\section{Pelaksanaan Pre Test}

Kegiatan pre-test dimaksudkan untuk mengukur pengetahuan awal peserta tentang pestisida kimia, pestisida nabati dan elisitor. Kegiatan pre-test dilaksanakan 15 menit sebelum pemberian materi, dimana peserta diberi soal bentuk pilihan ganda dan memilih satu jawaban yang paling tepat. Sejumlah 8 pertanyaan diberikan kepada 30 peserta. Hasil pre-test peserta penyuluhan/pelatihan penggunaan elisitor esktrak tumbuhan berdasarkan interval nilai ditunjukkan pada Tabel 1 .

Tabel 1. Hasil Pre-test Peserta Penyuluhan / Pelatihan Penggunaan Elisitor Esktrak Tumbuhan

\begin{tabular}{|c|c|c|c|}
\hline $\begin{array}{c}\text { Nomor } \\
\text { Soal }\end{array}$ & $\begin{array}{c}\text { Interval } \\
\text { Nilai }\end{array}$ & $\begin{array}{c}\text { Jumlah } \\
\text { (Orang) }\end{array}$ & $\begin{array}{c}\text { Prosentase } \\
(\%)\end{array}$ \\
\hline 1 & $0-1,25$ & 14 & 46.67 \\
\hline 2 & $1.26-2.50$ & 8 & 26.67 \\
\hline 3 & $2.51-3.75$ & 3 & 10.00 \\
\hline 4 & $3.76-5.00$ & 3 & 10.00 \\
\hline 5 & $5.01-6.25$ & 0 & 0.00 \\
\hline 6 & $6.26-7.50$ & 0 & 0.00 \\
\hline 7 & $7.51-8.75$ & 2 & 6.67 \\
\hline 8 & $8.76-100$ & 0 & 0.00 \\
\hline
\end{tabular}

Berdasarkan Tabel 1, prosentase nilai tertinggi pada range nilai $0-1,25$ yaitu sebanyak $47,67 \%$, diikuti range nilai $1,26-2.50$ yaitu $26.67 \%$, range nilai $2.51-3.75$ dan $3.76-5.00$ yaitu $10.00 \%$, range nilai $7.51-8.75$ yaitu 6.67 $\%$. Nilai terendah pada range nilai $5.01-6.25$, $6.26-7.50$, dan $8.76-100$ yaitu $0.00 \%$.

\section{Pelaksanaan Post-test}

Post-test dilaksanakan selama 15 menit setelah akhir ceramah / penyampaian materi, diskusi dan sharing pengalaman peserta penyuluhan. Sebanyak 8 soal diberikan pada 30 orang peserta dengan soal yang sama untuk pretest. Kegiatan post-test dimaksudkan untuk mengukur kemampuan daya serap dan pemahaman peserta penyuluhan setelah mengikuti penyajian materi.

Hasil post-test peserta penyuluhan / pelatihan penggunaan elisitor esktrak tumbuhan berdasarkan interval nilai dapat dilihat pada Tabel 2.

Tabel 2. Hasil Post-Test Peserta Penyuluhan/ Pelatihan Penggunaan Elisitor Esktrak 
VIVABIO

Jurnal Pengabdian Multidisiplin

Tumbuhan

\begin{tabular}{|c|c|c|c|}
\hline $\begin{array}{c}\text { Nomor } \\
\text { Soal }\end{array}$ & $\begin{array}{c}\text { Interval } \\
\text { Nilai }\end{array}$ & $\begin{array}{c}\text { Jumlah } \\
\text { (Orang) }\end{array}$ & $\begin{array}{c}\text { Prosentase } \\
(\%)\end{array}$ \\
\hline 1 & $0-1,25$ & 0 & 0.00 \\
\hline 2 & $1,26-2,50$ & 0 & 0.00 \\
\hline 3 & $2,51-3.75$ & 0 & 0.00 \\
\hline 4 & $3.76-5.00$ & 1 & 3.33 \\
\hline 5 & $5.01-6.25$ & 3 & 10.00 \\
\hline 6 & $6.26-7.50$ & 12 & 40.00 \\
\hline 7 & $7.51-8.75$ & 11 & 36.67 \\
\hline 8 & $8.76-100$ & 3 & 10.00 \\
\hline
\end{tabular}

Berdasarkan Tabel 2, terlihat terjadi peningkatan perolehan nilai hasil post-test. Sebanyak 12 orang memperoleh nilai dengan range $6.26-7.50,11$ orang memperoleh nilai dengan range $7.51-8.75,3$ orang memperoleh nilai dengan range 5.01-6.25 dan 8.76-100, dan 1 orang memperoleh nilai pada range 3.76-5.00.

Perbedaan jawaban peserta penyuluhan / pelatihan pada kegiatan pre-test dan post-test ditunujukkan pada Gambar 1.

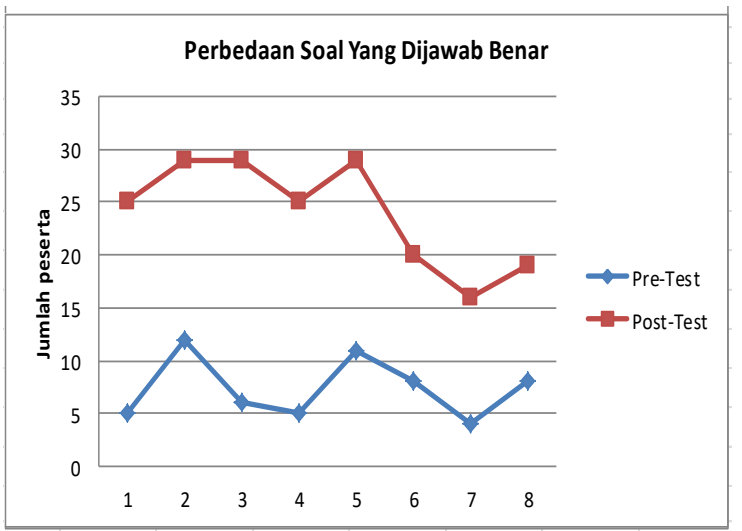

Gambar 1. Perbedaan Soal yang Dijawab Benar oleh Peserta Penyuluhan pada Pre-test dan Post-test

Berdasarkan Gambar 1, terlihat terjadi peningkatan pengetahuan tentang pestisida kimia, pestisida nabati dan elisitor. Jumlah soal yang dijawab benar oleh peserta yaitu pada soal nomor 2, 3, 5 sebanyak 29 orang, soal nomor 1 dan 4 dijawab benar oleh 25 orang, soal nomor 6 dijawab benar oleh 20 orang, soal nomor 8 dijawab benar oleh 19 orang, dan soal nomor 6 dijawab benar oleh 16 orang. Kegiatan penyuluhan ditunjukkan pada Gambar 2.
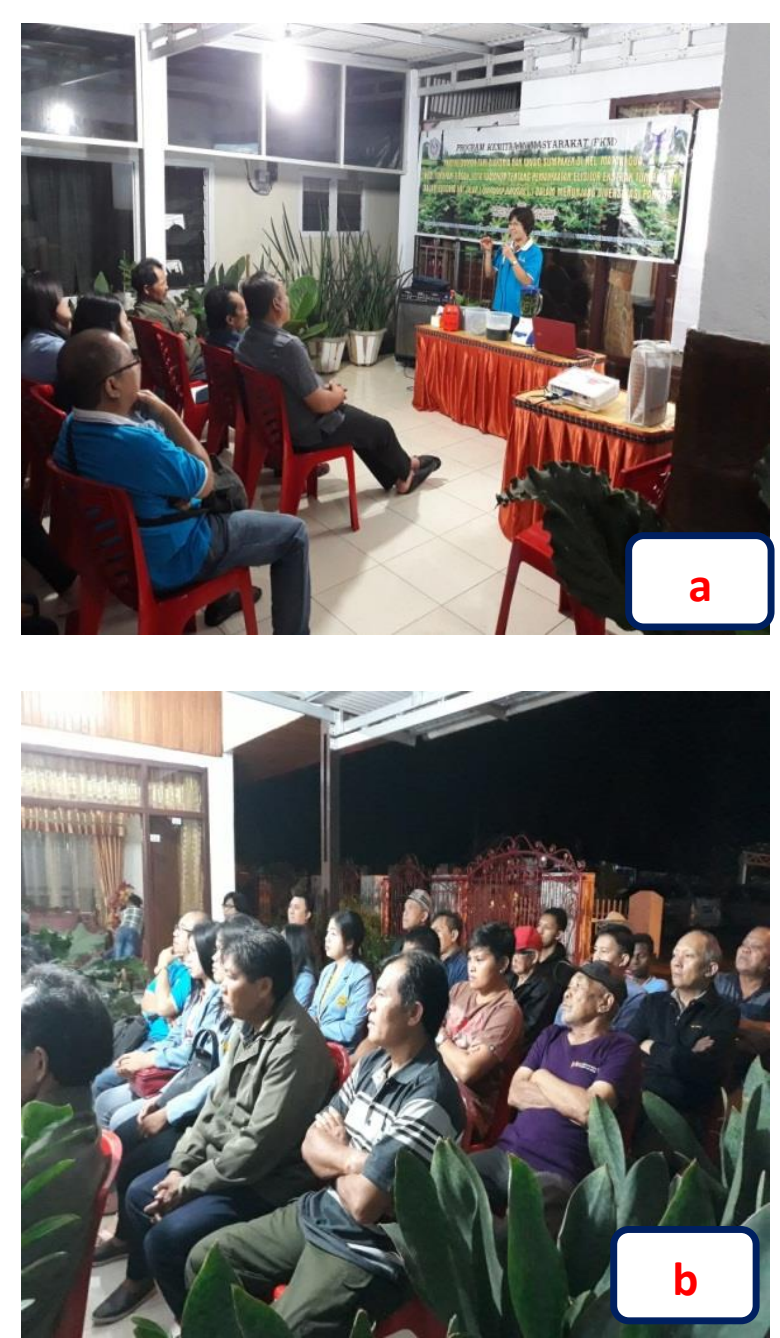

Gambar 1. Pemberian Materi (a), Peserta Penyuluhan dan Pelatihan (b)

Kegiatan PKM pada kelompok tani Diakonia dan Wawo Sumpaken tentang penggunaan elisitor memberikan dampak positif, yaitu terjadi peningkatan pengetahuan tentang pestisida kimia, nabati dan elisito (Gambar 1). Selain itu terjadi peningkatan ketrampilan dalam hal pembuatan elisitor tujuh jenis tumbuhan yaitu daun bayam duri (Amaranthus spinosus), alang-alang (Imperata cylindrica), daun alpukat (Persea americana), daun mangkokan (Nothopanax scutellarium), daun sirsak (Annona muricata), daun sirih (Piper betle) dan daun salam (Syzygium polyanyhum). 
VIVABIO

Jurnal Pengabdian Multidisiplin

Pada awalnya, pengetahuan elisitor dari peserta penyuluhan sangat rendah bahkan arti kata 'elisitor' belum pernah diketahui. Hal itu tergambar dari hasil pre-test yang sangat rendah yaitu range nilai $5.01-6.25,6.26-7.50$, dan 8.76 - 100 yaitu $0.00 \%$. Setelah pemberian materi dan diskusi terjadi transfer informasi kepada peserta, sehingga peserta mendapatkan pengetahuan tentang elsitor ekstrak tumbuhan. Peningkatan pengetahuan peserta terlihat dari hasil capaian nilai post-test dimana 11 orang memperoleh nilai dengan range $7.51-8.75$ (36.67\%), 3 orang memperoleh nilai dengan range 5.01-6.25 dan 8.76-100 (10.00\%).

Melalui kegiatan PKM para petani dapat mempraktekkan pengetahuan yang diperoleh dalam kegiatan bertani, sehingga dapat menekan adanya serangan hama dan penyakit pada tanaman budidaya, dan menghasilkan produk pertanian yang sehat dan bebas pestisida kimia.

Kegiatan PKM ini memberikan dampak positif bagi para petani dalam hal pengetahuan tentang elisitor ekstrak tumbuhan, bahkan memberikan nilai tambah berupa peningkatan pengetahuan dan ketrampilan dalam pemanfaatan elisitor ekstrak tumbuhan. Kegiatan PKM memberikan dampak positif dan perobahan perilaku petani, dalam hal teknik pengendalian hama dengan menekan penggunaan pestisida kimia yang memberi dampak negatif bagi organisme hidup dan lingkungan.

\section{KESIMPULAN DAN SARAN}

\section{Kesimpulan}

Hasil kegiatan penyuluhan menunjukkan terjadi peningkatan pengetahuan berdasarkan hasil post-test, yaitu sebanyak 3 orang (10\%) memperoleh nilai $8,76-100,11$ orang (36.67 $\%$ ) memperoleh nilai $7.51-8.75$, dan 12 orang (40\%) memperoleh nilai dengan range $6.26-$ 7.50. Kegiatan Program Kemitraan Masyarakat (PKM) dapat memotivasi petani menggunakan pestisida nabati dan elisitor ekstrak tumbuhan dalam kegiatan budidaya tanaman pangan.

\section{Saran}

Untuk meningkatkan produksi dalam menunjang diversifikasi dan kemandirian pangan berbasis pertanian organik, salah satu strategi dalam pengendalian hama pada tanaman pangan dan hortikultura yaitu dengan menggunakan elsitor ekstrak tumbuhan.

\section{UCAPAN TERIMAKASIH}

Terima kasih disampaikan kepada Rektor Universitas Sam Ratulangi Manado dan Ketua Lembaga Penelitian dan Pengabdian Pada Masyarakat UNSRAT, yang telah memberikan bantuan dana melalui Skim PKM sumber dana PNBP Tahun 2018. Terima kasih juga kepada ketua dan anggota kelompok Tani Wawo Sumpaken dan Diakonia yang menjadi mitra dalam kegiatan PKM ini.

\section{DAFTAR PUSTAKA}

Angelova, Z., S. Georgiev and W. Roos. 2006. Elicitation of Plants. Biotechnol. \& Biotechnol. Eq. 20(2) : 72-83.

Arotaa, A.N., T.M. Katiandago dan O. Benu. 2016. Hubungan Antara Luas Lahan Pertanian dengan Produk Domestik Regional Bruto Pertanian di Kota Tomohon. ASE 12(1): $13-28$.

Asmaliyah., E.E. Wati., S. Utami., K. Mulyadi, Yudhistira dan F.W. Sari. Pengenalan Tumbuhan Penghasil Pestisida Nabati dan Pemanfaatannya Secara Tradisional. Libang Produktifitas Hutan. Jakarta.

BPS 2017. Kota Tomohon. ppsp. nawasis. info/.../pokja/.../kota.tomohon/BAB\%20II \%20BPS\%20TOMOHON (Diakses 2 Desember 2017)

Butarbutar, R.; M.C. Tobing dan M.U. Tarigan. 2013. Pengaruh Beberapa Jenis Pestisida Nabati Untuk Mengendalikan Ulat Grayak Spodoptera litura (Lepidoptera : Noctuidae) pada Tanamana Tembakau Deli di Lapangan. Jurnal Online Agroekoteknologi 1(4). ISSN No. 23376597.

Gunaeni, N.; A.W. Wulandari dan A. Hudayya. 2015. Pengaruh Bahan Ekstrak Tanaman Terhadap Pathogenesis Related Protein dan Asam Salisilat dalam Menginduksi Resistensi Tanaman Cabai Merah 
VIVABIO

Jurnal Pengabdian Multidisiplin

terhadap Virus Kuning Keriting. J.Hort. 25(2): 160-170.

Havelka, J. 2009. Biopesticides of Plant Origin. Eur. J. Entomol. 106: 224, http://www.eje.cz/scripts/viewabstract.php ?abstract=1455 ISSN 1210-5759 (print), 1802-8829 (online). Diakses 2 tanggal 3 Maret 2017.

Kardinan, A. 2001. Pestisida Nabati, Ramuan dan Aplikasi. Penebar Swadaya. Jakarta.

Laoh, E. 2008. Buku Ajar Ekonom Pembangunan, Fakultas Pertanian Universitas Sam Ratulangi, Manado.

Leiss, K.A.; Y.H. Choi; R. Verpoorte and G.L.K Peter. 2011. An Overview of NMR-Based Metabolimics to Identify Secondary Plant Compounds Involved in Host Plant Resistance. Phytochem Rev. 10 : 205 2016.

Mallarangeng, R. ; A. Nurmas \& Asniah. 2012. Efikasi Pestisida Nabati Dari Tanaman Sela Jambu Mete dan Jamur Entomopatogen Synnematium sp. untuk Mengendalikan Wereng Pucuk Mete (Sanurus indecora). J. HPT Tropika 12( 2): $146-152$

Namdeo, A.G. 2007. Review Article : Plant Cell Elicitation for Production of Secondary Metabolites. Pharmacognosy Reviews 1(1) : 69-79.

Novizan. 2002. Membuat dan Memanfaatkan Pestisida Ramah Lingkungan. Agromedia Pustaka. Jakarta.

Sastrohamidjojo, H. 1996. Sintesis Bahan Alam. Gadjah Mada University Press. Yogyakarta.

Somowiyaryo, S.; Y.B. Sumardiyono dan S. Martoso. 2001. Inaktif CMV dengan Ekstrak Mirabillis jalapa. Prosiding Kongres Nasional XVI dan seminar PFI. Bogor. Hal. 218-220.

Suganda, T. 2000. Introduction of Resistance of Red Papper Against Fruit Antracnose by The Application of Biotic and Abiotic Inducers. J. Agrikultura. 11:72-78

Verma, H.N. ; S. Srivastrava, Varsha and Kumar. 1996. Induction of Systemic Resistance in Plants Againts Viruses by Basic Protein From Clerodendrum aculeatum Leaves. Phytopathol. 86(1) : 485-492.

Walters, D. ; D. Walsh; A. Newton and G. Lyon. 2005. Induced Resistance for Plant Disease Control : Maximizing the Efficacy of resistance Elicitors. Phytopathology 95 : 1368-1373.

Zhao, J. ; L. Davis and R. Verpoorte. 2005. Elicitor Signal Transduction Leading to Production of Plant Secondary Metabolites. Biotechnol.Adv. 23:283333 